\title{
Relation between family functionality and the household arrangements of the elderly
}

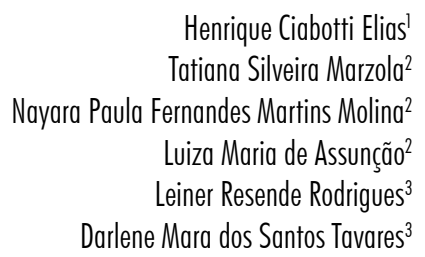

Abstract

Objective: to verify the association between family functionality and the household arrangements of the elderly in an urban area of Minas Gerais. Method: a quantitative, household survey type study that was analytical, cross-sectional and observational in nature was carried out with 637 elderly persons. The Mini Mental State Examination, a characterization of sociodemographic and economic data and the Family Apgar test were used. Descriptive analysis was performed by absolute and relative frequencies for the categorical variables. The Chi-squared test $(p<0.05)$ was used to identify relationships between household arrangements and family functionality. Results: elderly women $(66.6 \%)$, aged 60 to 70 years $(42.1 \%)$, who were married $(42.7 \%)$, and received the minimum wage $(45.1 \%)$, with up to four years of education $(51 \%)$ predominated. It was found that the majority of the elderly persons interviewed $(87.8 \%)$ considered their family as a unit of care with good functionality. There was a significant association between poor family functionality and elderly individuals who lived alone $(p=0.007)$. Conclusion: it is important to understand the family dynamics of the elderly so that multidisciplinary teams can promote actions and interventions aimed at the needs of each family, helping to strengthen family relationships.

Universidade Federal do Triângulo Mineiro. Curso de Graduação em Enfermagem. Uberaba, Minas Gerais, Brasil.

2 Universidade Federal do Triângulo Mineiro. Programa de Pós-Graduação em Atenção à Saúde. Uberaba, Minas Gerais, Brasil.

3 Universidade Federal do Triângulo Mineiro. Departamento de Enfermagem em Educação e Saúde Comunitária.Programa de Graduação em Enfermagem. Uberaba, Minas Gerais, Brasil.

Research funding: Minas Gerais Research Support Foundation, process number 02035-14, Undergraduate research grant.

Correspondence

Luiza Maria de Assunção

luassunc@gmail.com
Keywords: Family Relations. Elderly. Family. 


\section{INTRODUCTION}

Longevity requires a greater need for care. The family is therefore fundamental to the elderly person, representing an informal network of support for this population group ${ }^{1,2}$. In the present study, those who cohabit with the elderly are considered family.

The family fulfills an important role in society, especially among the elderly population and particularly in relation to support, protection, belonging and affect $^{3}$. It is a complex and unique context with interactions that must be explored and a network of relationships in which the attitudes of one member affect the whole group ${ }^{4}$.

Due to the social evolutions of recent times, the concept of the family has undergone constant transformations, giving rise to new types of organization, structure, culture, religion and relationships, which are often difficult to understand ${ }^{5}$. Such changes in family composition have occurred due to the greater participation of women in the labor market, low fertility rates and the aging of the population, triggering intergenerational conviviality ${ }^{6}$. In this context, changes in the contributions and attributions of different family members occur.

In the last year $30.6 \%$ of the elderly, mainly women $(33.3 \%)$, were found to live with their children or another relative. The proportion of elderly men living alone was $15.1 \%$, while for elderly women it was $17.8 \%$. Therefore, $84.9 \%$ of Brazilian elderly persons lived with some kind of family relation. A total of $29 \%$ of households contained at least one elderly person aged 60 or over?

Since 1960, the structure of families has been changing, due to characteristics of modern society such as individualism, resulting in significant changes in intra-family relationships ${ }^{8,9}$. In Brazil, the number of people living alone, including the elderly, has increased. This has occurred due to issues related to the demands of modernity that value individualism, but also by factors such as: changes in cultural behavior, more common marital separation and increased life expectancy?

Household arrangements are concerned with the number of members that make up a family unit as well as the consanguineous and generational relationships between them ${ }^{10}$. Living together with children and grandchildren is normally determined by the degree of physical incapacity and financial needs of the elderly ${ }^{10}$.

The existence of socio-historical-cultural aspects as well as political, economic and demographic factors influences the configuration of household arrangements involving the elderly. Thus, the type of arrangement does not depend exclusively on the decision of the elderly person and their relatives. ${ }^{9}$. For example, living in the urban environment produces a greater sense of individualism in people, which in turn can influence the constitution of household arrangements. In such cases there are a greater number of people who have chosen to live alone?

The affective function of the family is extremely important. In a functional family system both emotional and affective aspects are present. From the perspective of family functionality, members tend to deal with conflicts and adversities in order to achieve emotional stability, using their own resources for effective solutions $\mathrm{s}^{11,12}$. Also related to family functionality is the distribution of roles and support among the members of the family ${ }^{4,13}$.

Conversely, in a context of poor family functioning, the care capacity of family groups may be impaired, which makes them unsuccessful at adequately meeting the care needs of their elderly relatives. This fact could lead to impairment in the process of autonomy and quality of life of the elderly ${ }^{14}$. Poor functionality is associated with the inability to cope with crisis situations and the failure to perform essential functions such as: adaptation, companionship, member development, affectivity, and problem solving ability ${ }^{15}$.

Family functioning is threatened by conditions that lead the elderly to depend on the family, such as chronic non-communicable diseases. The difficulties of family adjustment and reorganization related to these pathologies are based on negative emotional patterns that may influence family life ${ }^{15,16}$. The household arrangement is capable of improving or further impairing the dynamics of the family and the quality of life of the elderly ${ }^{17,18}$.

This issue is worrying, as longevity accompanied by Noncommunicable Chronic Diseases (DCNT) 
and disabilities consequently increases the number of elderly people who require care by professionals and especially the family. For the elderly, the family is their mainstay, and this support becomes essential for coping with problems and satisfaction in family relationships and life.

The objective of the present study was therefore to verify the association of family functionality with the home arrangements of the elderly in an urban area.

\section{METHOD}

A household survey type study with a quantitativeanalytical, observational and cross-sectional approach was carried out with elderly persons living in the community from a municipal region in the rural part of the Triângulo Mineiro region, Minas Gerais.

The population was composed of elderly people aged 60 years and over of both genders, a group which was estimated for the urban area as being 315,360 inhabitants. We included individuals aged 60 years or older; residents of the urban area; who were without cognitive decline according to the Mini Mental State Exam (MMSE) ${ }^{19}$ score. The cut-off point for cognitive decline was the level of schooling of the respondent, corresponding to 13 points for those who were illiterate, 18 points or less for those with 1 to 11 years of schooling and 26 points for over 11 years of schooling.

It is worth noting that the multi-stage cluster sampling process of the present study is part of a larger study entitled "Dependence in activities of daily living, frailty and the use of health services among elderly people in the Triângulo Mineiro" developed by the research group in Public Health of the Universidade Federal do Triângulo Mineiro (UFTM), the sample size of which was calculated as $\mathrm{N}=711$. Although the sample size was calculated for multiple correlations, in accordance with the larger study, the present study discusses the results of bivariate analyzes.

The selection of the elderly persons was by arbitrary drawing of $50 \%$ of the urban census tracts of the municipal region, according to a single list of said tracts $(\mathrm{N}=409)$, with 204 sectors obtained. Sectors with no elderly persons, without homes and those that did not include the number of elderly residents were excluded, as well as individuals who were not located after three attempts.

The number of interviews was divided by the census tracts drawn. These were conducted in the home by trained researchers (undergraduate and graduate students in the area of health) and were reviewed by field supervisors (teachers and postgraduate students). The first household to be interviewed was randomly selected and the subsequent interviews were carried out in the households in a standardized manner until the sector was saturated. The number of households/elderly persons was considered as four elderly persons per census tract.

Data collection occurred from January to April 2014 , in the respective residences of the elderly.

Regarding the study variables, the sociodemographic aspects were: gender (female/male), age group (60-70, $70-80,80$ or over), marital status (single, married or living with partner, widower, separated/divorced), schooling (no schooling, $1-4,4-8,8$ or more), monthly individual income $(<1 ; 1 ; 1-3 ; 3-5 ;>5)$; using an instrument prepared by the authors, who were part of the Research Group in Public Health/UFTM ${ }^{20}$.

The Family Apgar, developed by Smilkstein (1978) and translated and adapted transculturally in Brazil in 2001 by Duarte ${ }^{21}$ was used to measure family functioning. This instrument evaluates the dynamics of the family in relation to five aspects: Adaptability, Partnership, Growth, Affection, and Resolve. The answers are selected from: $0=$ never, 1 $=$ rarely, $2=$ sometimes, $3=$ almost always and $4=$ always. The total score is classified as: high familial dysfunction - 0 to 8; moderate family dysfunction - 9 to 12 or good functionality - 13 to 20 points.

A descriptive analysis of the categorical variables was performed based on absolute and relative frequencies. To verify the association between family functionality and household arrangement, the chi-squared test was performed, considering a level of significance of $p<0.05$. A database was organized in a spreadsheet by independent double entry. Inconsistencies were observed and the research instruments were reapplied to correct them. For the statistical analysis, the information was transposed to the "Statistical Package for Social Sciences" (SPSS) version 21.0 software package. 
The study was approved by the Ethics Research Committee of UFTM, under protocol No 493.211. The Free and Informed Consent Form was signed by all the participants of the research, following the precepts established by Resolution 466/12, dated $12 / 12 / 2012$, of the Ministry of Health ${ }^{22}$.

\section{RESULTS}

Of the 711 elderly persons, 637 elderly were analyzed in the present study, with refusals, Apgar answered by the caregiver/relative and withdrawals considered as losses. The reasons for withdrawals given by the elderly were: health problems at the time of the interview, commitments outside the home, visitors or because they found the questionnaire too long. A total of 637 elderly people therefore participated.

In relation to socio-demographic and economic data, there was a higher percentage of elderly women, aged 60-70 years, who were married, had $1-4$ years of schooling, an income of one minimum salary and lived with others (Table 1).

There was a predominance of interviewees who considered their family relationship to have good functionality (87.8\%), while only $5.8 \%$ had families with fair functionality and $6.4 \%$ had poor functionality.

Table 2 shows the association between family functionality and home arrangement.

Table 1. Distribution of elderly persons according to sociodemographic and economic variables. Uberaba, Minas Gerais, 2014.

\begin{tabular}{|c|c|}
\hline Variables & $\mathrm{n}(\%)$ \\
\hline \multicolumn{2}{|l|}{ Gender } \\
\hline Male & $213(33.4)$ \\
\hline Female & $424(66.6)$ \\
\hline \multicolumn{2}{|l|}{ Age group } \\
\hline $60-70$ & $268(42.1)$ \\
\hline $70-80$ & $234(36.7)$ \\
\hline 80 or more & $135(21.2)$ \\
\hline \multicolumn{2}{|l|}{ Marital Status } \\
\hline Single & $47(7.4)$ \\
\hline Married or live with partner & $272(42.7)$ \\
\hline Widow/widower & $254(39.9)$ \\
\hline Separated $\backslash$ divorced & $64(10.0)$ \\
\hline \multicolumn{2}{|l|}{ Schooling (in years of study) } \\
\hline No schooling & 131(20.6) \\
\hline $1-4$ & $325(51.0)$ \\
\hline $4-8$ & $54(8.5)$ \\
\hline 8 or more & $127(19.9)$ \\
\hline \multicolumn{2}{|c|}{ Monthly Individual Income (in minimum salaries)* } \\
\hline No income & $60(9.4)$ \\
\hline$<1$ & $15(2.4)$ \\
\hline 1 & $287(45.1)$ \\
\hline $1-3$ & $207(32.5)$ \\
\hline $3-5$ & $42(6.6)$ \\
\hline$>5$ & $26(4.1)$ \\
\hline \multicolumn{2}{|l|}{ Household Arrangement } \\
\hline Lives alone & $129(20.3)$ \\
\hline Lives with others & $508(79.7)$ \\
\hline
\end{tabular}

*According to the Department of Statistics and Socioeconomic Studies (DIEESE), the minimum salary in 2014 was 724 reais. 
Table 2. Association between family functionality and the household arrangements of the elderly. Uberaba, Minas Gerais, 2014.

\begin{tabular}{llll}
\hline & \multicolumn{3}{c}{ Household arrangement } \\
& Lives alone $(\mathrm{n} \%)$ & Lives with others $(\mathrm{n} \%)$ & $p$ \\
\hline Family functioning & & & 0.007 \\
Poor & $16(12.5)$ & $25(4.9)$ & \\
Fair & $6(4.7)$ & $31(6.1)$ & $453(89.0)$ \\
Good & $106(82.8)$ & & \\
\hline
\end{tabular}

The results of the chi-squared test identified an association between family functionality and household arrangement, with those who lived alone having poor functionality ( $\mathrm{p}=0.007$ ) in comparison with those that lived with others.

\section{DISCUSSION}

The predominance of women in this study is

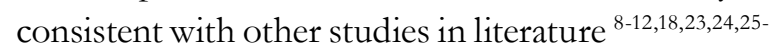
27 . These data corroborate the greater life expectancy and health concerns of the elderly female population in Brazil and in most countries of the world ${ }^{1,7}$.

Regarding the predominant age group (60-70), the data are consistent with other studies that consider the relationship between the elderly and family relationships and their support network ${ }^{18,26}$.

Regarding marital status, Brazilian studies found higher prevalences of married elderly persons in three municipal regions: Poços de Caldas, Minas Gerais (52.4\%), Campinas, São Paulo (51.8\%) and Ivoti, Rio Grande do Sul (53.3\%). The prevalences of widows found in the municipal regions of Parnaíba, Piauí (38.1\%), Campinas, São Paulo (38.5\%) and Ivoti, Rio Grande do Sul (40.6\%) were similar to those of the present study ${ }^{28}$.

In terms of schooling, more than half (51\%) of the respondents reported having $1-4$ years of schooling and $20.6 \%$ had no schooling, a result similar to a study of elderly persons living in the community in the east of São Paulo, which had findings of $61.6 \%$ and $18 \%$, respectively ${ }^{29}$. In another study with the elderly in Campinas, São Paulo, similar percentages were found to our study $(54.2 \%$ and $18.2 \%),{ }^{28}$.
Low levels of schooling impair self-care, ${ }^{30}$ access to information, the obtaining of one's rights, absorption of knowledge and health awareness ${ }^{31}$.

The low income of the elderly persons interviewed corroborates the values found in some regions of Brazil, where $41.6 \%$ have an income of one minimum salary. The majority of this group of elderly persons live in the north (59.6\%) and northeast (61.2\%) of the country ${ }^{7}$. A study conducted in Dourados (Mato Grosso) with 374 elderly people found that $51.9 \%$ had a per capita income of half a minimum wage ${ }^{27}$.

Restrictions imposed by one's financial situation can affect access to health and self-care and may lead to housing deprivation, family abandonment, the loss of assets and impact on family relationships ${ }^{18,25}$.

The predominance of elderly persons who lived with others was also found in studies carried out in Mato Grosso do Sul $(80.5 \%)^{27}$, Bahia $(77.7 \%)^{25}$ and Goiás $(81.5 \%)^{16}$. The percentages of elderly individuals who said they lived alone were similar to those found in the FIBRA (Network for the Study of Frailty in the Brazilian Elderly) network in the cities of Poços de Caldas (Minas Gerais) (19.8\%) and Ivoti (Rio Grande do Sul) $(21.3 \%)^{28}$.

It is essential for professionals to strengthen the bond between elderly persons, their families and health professionals, since the elderly believe that the family is a source of support and security, as well as being a foundation for dealing with difficulties and care ${ }^{31}$.

In addition, guidance on rights and guarantees of the elderly should be provided, strengthening family ties so that they can have a healthier old age ${ }^{31}$, and thus better family functionality ${ }^{12}$. 
Living with relatives is desired by the elderly, since they believe their loved ones will provide attention and care when necessary, although the family's capacity to do so may be impaired ${ }^{32}$. Knowing how families relate involves guidance in clinical practice, enabling family members to live together in a more healthy and harmonious manner.

Regarding the evaluation of family Apgar, some studies with the elderly have found good family functioning $(76.3 \%, 85 \%$ and $85.19 \%$, respectively) $17,25,33$, as did the present study. A functional family can provide the elderly with the support and security they need at this stage of life $^{27}$.

Individuals who lived alone were associated with families with poor functionality, corroborating the findings of other studies ${ }^{16,17}$. Poor social support and a precarious bond with relatives can result in family insufficiency in the elderly ${ }^{34}$. The aging process requires more support and care from families. This should accompany the experience of growing old, identifying possible difficulties and promoting better living conditions ${ }^{34}$.

Elderly persons who live alone experience moments of loneliness, insecurity, sadness, low self-esteem, triggering social isolation which, once installed, tends to be accentuated, hampering family ties $^{34}$. A lack of dialogue, reduced family and social support, limited family time, and lack of participation in decision-making processes may compromise the family functioning and general health conditions of the elderly $y^{16,34}$.

Living with other people allows greater intimacy and closeness, promoting affect, reciprocity and stability for the elderly in order to allow harmonious relationships ${ }^{18}$. At the same time, living in and with families with people of different generations can be conflicting and even trigger poor functionality in families. However, it differs from living alone if there is understanding, respect and acceptance to overcome difficulties ${ }^{18}$. The elderly today have assumed new roles of responsibility, commitment and care, characterized by respect and greater participation in family relationships, which can contribute to balance and better family functionality ${ }^{11,18}$.

Living alone has a negative effect in comparison with living with another person as being alone can impair self-care, cause functional decline, and lead to a greater propensity for depression. In addition, it can cause both social isolation and inferior family relationships, as it can result in the lack of a caregiver ${ }^{16,27,34}$.

In this sense, professionals should advise the elderly and their families about the importance of social support networks and establish a network of care, especially for those who live alone ${ }^{26}$.

In terms of limitations, one of those faced by the present study is the lack of investigations for comparison.

Despite not reaching all the sample proposed in the research plan, the phenomenon was studied among 637 community-based elderly persons, which makes it possible to generalize the findings to similar populations.

Another limitation is the cross-sectional design of the study, meaning family functionality was assessed in a single moment. A critical event, which may not be recurrent, may therefore have affected this perception among the elderly. However, considering the gap in scientific production on the subject, the analysis carried out provides proposals for the understanding of family functioning and household arrangements among the elderly population.

\section{CONCLUSION}

The present study found a predominance of elderly women, aged between 60 and 70 years, who were married, had four years of schooling, earned minimum wage and lived with others. Most considered their family functioning to be good. Poor family functioning was associated with elderly persons who lived alone.

It is therefore important to identify the family dynamics of these elderly persons, so that multidisciplinary teams can offer actions and interventions geared to the needs of each family, promoting the strengthening of family relationships.

The present study provides a basis for the development of new research on the elderly and family functionality. Studies with elderly persons 
living alone and the available sources of social support are suggested, as well as the evaluation of this support for the elderly population.

The results support the development of future studies on the application of instruments such as Apgar, which represents a reference for the recognition residing elderly population. The analyzes undertaken

also allowed associations to be established among the variables. These results can support multi-professional training and the improvement of teamwork when dealing with the family of the elderly.

It can also support reflection on programs and policies for the elderly who live alone and, therefore, cannot rely on the support of family functionality to manage their condition.

8. Vera I, Lucchese R, Nakatani AYK, Pagotto V, Montefusco SRA, Sadoyama G. Funcionalidade familiar em longevos residentes em domicílio. Rev Bras Enferm. 2015;68(1):68-75.

9. Melo NCV, Teixeira KMD, Barbosa TL, Montoya AJA, Silveira MB. Arranjo domiciliar de idosos no Brasil: análises a partir da Pesquisa Nacional por Amostra de Domicílios (2009). Rev Bras Geriatr Gerontol [Internet]. 2016 [acesso em 29 jul. 2017];19(1):139-51. Disponível em: http://www. redalyc.org/pdf/4038/403844773013.pdf

10. Rabelo DF, Neri AL. Tipos de configuração familiar e condições de saúde física e psicológica em idosos. Cad Saúde Pública. 2015;31(4):874-84.

11. Santos AL, Cecílio HPM, Teston EF, Marcon SS. Conhecendo a funcionalidade familiar sob a ótica do doente crônico. Texto \& Contexto Enferm. 2012;21(4):879-86.

12. Martins R, Mestre M. Esperança e qualidade de vida em idosos. Millenium [Internet]. 2014 [acesso em 14 jul. 2017];47:153-62. Disponível em: http://www.ipv. $\mathrm{pt} / \mathrm{millenium/Millenium47/13.pdf}$

13. Brasil. Ministério da Saúde, Secretaria de Atenção à Saúde, Departamento de Atenção Básica. Envelhecimento e saúde da pessoa idosa [Internet]. Brasília, DF: Ministério da Saúde; 2007 [acesso em 20 ago. 2017]. Disponível em: http://bvsms.saude.gov. br/bvs/publicacoes/abcad19.pdf

14. Floriano LA, Azevedo RCS, Reiners AAO, Sudré MRS. Cuidado realizado pelo cuidador familiar ao idoso dependente, em domicílio, no contexto da estratégia de saúde da família. Texto \& Contexto Enferm. 2012;21(3):543-8.

15. Rabelo DF, Neri AL. Arranjos domiciliares, condições de saúde física e psicológica dos idosos e sua satisfação com as relações familiares. Rev Bras Geriatr Gerontol. 2015;18(3):507-19. 
16. Vera I, Lucchese R, Nakatani AYK, Sadoyama G, Bachion MM, Vila VSC. Fatores associados à disfuncionalidade familiar em idosos não institucionalizados. Texto \& Contexto Enferm. 2015;24(2):494-504.

17. Campos ACV, Rezende GP, Ferreira EF, Vargas AMD, Gonçalves LHT. Funcionalidade familiar de idosos brasileiros residentes em comunidade. Acta Paul Enferm [Internet]. 2017 [acesso em 29 jul. 2017];30(4):358-67. Disponível em: http://www.scielo. br/pdf/ape/v30n4/0103-2100-ape-30-04-0358.pdf

18. Silva DM, Vilela ABA, Nery AA, Duarte ACS, Alves MR, Meira SS. Dinâmica das relações familiares intergeracionais na ótica de idosos residentes no município de Jequié (Bahia), Brasil. Ciênc Saúde Colet. 2015;20(7):2183-91.

19. Bertolucci PHF, Brucki SMD, Campacci SR, Juliano Y. O mini-exame do estado mental em uma população geral: impacto da escolaridade. Arq Neuropsiquiatr [Internet]. 1994 [acesso em 29 jul. 2017];52(1):1-7. Disponível em: http://www.scielo.br/ pdf/anp/v52n1/01.pdf

20. Rodrigues LR, Tavares DS, Dias FA, Pegorari MS, Marchiori GF, Tavares DMS. Qualidade de vida de idosos comunitários e fatores associados. Rev Enferm UFPE [Internet]. 2017 [acesso em 29 jul. 2017];11(Supl. 3):1430-8. Disponível em: https://periodicos.ufpe.br/ revistas/revistaenfermagem/article/view/13985

21. Duarte YAO. Família: rede de suporte ou fator estressor: a ótica de idosos e cuidadores familiares [Tese]. São Paulo: Universidade de São Paulo, Escola de Enfermagem; 2001.

22. Conselho Nacional de Saúde. Resolução no 466, de 12 de dezembro de 2012. Aprova diretrizes e normas regulamentadoras de pesquisa envolvendo seres humanos. Brasília, DF: CNS; 2012. Disponível em: http://bvsms.saude.gov.br/bvs/saudelegis/cns/2013/ res0466_12_12_2012.html

23. Loureiro LSN, Fernandes MGM, Nóbrega MML, Rodrigues RAP. Sobrecarga em cuidadores familiares de idosos: associação com características do idoso e demanda de cuidado. Rev Bras Enferm. 2014;67(2):227-32.

24. Oliveira SC, Santos AA, Pavarini SCI. Relação entre sintomas depressivos e a funcionalidade familiar de idosos institucionalizados. Rev Esc Enferm USP. 2014;48(1):66-72.

Received: May 01, 2018

Reviewed: July 26, 2018

Accepted: July 31, 2018
25. Reis LA, Torres GV, Reis LA, Santos KT. Influência da dinâmica familiar na qualidade de vida de idosos. Rev Pesqui Fisioter [Internet]. 2014 [acesso em 29 jul. 2017];4(2):123-30. Disponível em: https://www5. bahiana.edu.br/index.php/fisioterapia/article/ view/399/310

26. Silveira VC, Paskulin L. Perfil e rede de apoio de idosos internados na emergência do hospital de clínicas de Porto Alegre. Estud Interdiscip Envelhec. 2014;19(2):377-96.

27. Souza RA, Costa GD, Yamashita CH, Amendola F, Gaspar JC, Alvarenga MRM, et al. Funcionalidade familiar de idosos com sintomas depressivos. Rev Esc Enferm USP. 2014;48(3):469-76.

28. Neri AL, Yassuda MS, Araújo LF, Eulálio MC, Cabral BE, Siqueira MEC, et al. Metodologia e perfil sociodemográfico, cognitivo e de fragilidade de idosos comunitários de sete cidades brasileiras: estudo FIBRA. Cad Saúde Pública. 2013;29(4):778-92.

29. Batistoni SST, Prestes SM, Cachionia M, Falcão DVS, Lopes A, Yassuda MS, et al. Categorização e identificação etária em uma amostra de idosos brasileiros residentes na comunidade. Psicol Reflex Crít. 2015;28(3):511-21.

30. Caldeira S, Merighi MAB, Muñoz LA, Jesus MCP, Domingos SRF, Oliveira DM. O enfermeiro e o cuidado à mulher idosa: abordagem da fenomenologia social. Rev Latinoam Enferm [Internet]. 2012 [acesso em 04 ago. 2017]; 20(5):1-8. Disponível em: http:// www.scielo.br/pdf/rlae/v20n5/pt_10.pdf

31. Oliveira NS, Souza TS, Alencar FS, Oliveira GL, Ferreira NB, Alencar JS. Percepção dos Idosos sobre o processo de envelhecimento. Rev Psicol [Internet]. 2014 [acesso em 10 jun. 2015];8(22):49-83. Disponível em: https://idonline.emnuvens.com.br/id/article/ view/264/376

32. Paiva ATG, Bessa MEP, Moraes GLA, Silva MJ, Oliveira RDP, Soares AMG. Avaliação da funcionalidade de famílias com idosos. Cogitare Enferm [Internet]. 2011 [acesso em 29 jul. 2017];16(1):22-8. Disponível em: http://revistas.ufpr. br/cogitare/article/viewFile/21107/13933

33. Polaro SHI, Gonçalves LHT, Nassar SM, Lopes MMB, Ferreira VF, Monteiro HK. Dinâmica da família no contexto dos cuidados a adultos na quarta idade. Rev Bras Enferm. 2013;66(2):228-33.

34. Souza A, Pelegrini TS, Ribeiro JHM, Pereira DS, Mendes MA. Conceito de insuficiência familiar na pessoa idosa: análise crítica da literatura. Rev Bras Enferm. 2015;68(6):1176-85. 